\section{SPATIAL ORGANIZATION AND FURNISHING OF THE SCHOOL CLASSROOM: THE INITIAL DEVELOPMENT PERIOD (XIII-XVII CT.)}

Danylo Kosenko, https://orcid.org/0000-0002-1668-6911 Senior Lecturer of Department of Interior and Furniture Design, Kyiv National University of Technologies and Design, Kyiv, Ukraine danylo.kosenko@gmail.com

\section{ПРОСТОРОВА ОРГАНІЗАЦІЯ \\ ТА МЕБЛЮВАННЯ ШКІЛЬНОГО КЛАСУ: ПОЧАТКОВИЙ ПЕРІОД РОЗВИТКУ (XIII-XVII СТ.)}

\section{Данило Косенко,} https://orcid.org/0000-0002-1668-6911 доцент кафедри дизайну інтер'єру і меблів, Київський національний університет технологій і дизайну, Київ, Україна danylo.kosenko@gmail.com

Анотація

The aim of the research. The study is aimed to identify and characterize the features of the spatial organization and furnishing of the educational facilities of the European mass schools at the initial stages of their formation and development (approximately XIII-XVII centuries). Research methods. Historical-cultural and comparative methods have been used. The source base includes artworks of the period depicting a school interior. In addition, written sources of the period and the results of contemporary historical and cultural studies have been largely involved. Scientific novelty. The features of spatial organization and furnishing of school classes in the initial period of the development of mass school education in Europe (approximately XIII-XVII ct.) are systematically described for the first time, the key stages of mentioned period are highlighted. Conclusions. The initial period of development of spatial organization and furnishing of school space is limited by XIII-XVII centuries. The key features of this period are as follows: a) spatial organization of the class, suitable only for individual work of students, b) the use of nonspecialized furniture (household chairs, benches and tables). Three stages can be distinguished in this period. The first stage (XIII-XVI centuries) is characterized by the equipment of ateacher's place only (chair-cathedra and table or bookrest). The second stage (XVI-XVII centuries) differs from the first one by the introduc
Мета дослідження. Виявити та охарактеризувати особливості просторової організації та меблювання навчальних приміщень європейської масової школи на початкових етапах становлення та розвитку (орієнтовно XIII-XVII ст.). Методи дослідження. Історико-культурний та компаративний методи. Джерельною базою є історичні зображення шкільного облаштування названого періоду в образотворчому мистецтві та в інших візуальних джерелах. Додатково залучались текстові свідчення та результати сучасних історико-культурних досліджень. Наукова новизна. Вперше систематично описано особливості просторової організації та меблювання шкільних класів у початковому періоді розвитку масової шкільної освіти у Європі (орієнтовно XIII-XVII ст.), виділено ключові етапи зазначеного періоду. Висновки. Початковий період розвитку просторової організації та облаштування шкільного простору окреслено межами XIIIXVII ст. Ключовими ознаками цього періоду $€$ a) просторова організація класу, що придатна лише для індивідуальної роботи учнів, б) використання неспеціалізованого меблювання (побутових крісел, лав та столів). У цьому періоді можна виділити три ється обладнанням лише вчительського місця (крісло-кафедра та стіл або пюпітр). Другий етап (XVI-XVII ст.) вирізняється заетапи. Перший (XIII-XVI ст.) характеризу- 
tion of writing workplaces for pupils, as well as demonstration equipment (blackboards, tables, appliances, etc.). The spatial organization of the class has a spontaneous character. In the third stage (from the middle of the XVII ct.) there are first attempts to introduce systematic organization, zoning of the classroom space, development of functional centers of different purposes, fixing the pupils' workplaces. Equipping the classroom with frontal-oriented rows of specialized pupils' furniture (tables with oneside workplaces) in the XVIII ct. could be treated as the sign of the transition to the next period.

\section{Keywords:}

learning space, school, classroom, classroom spatial organization, school furnishing, classroom furniture, school history. провадженням столів для письмової роботи учнів, а також демонстраційного обладнання (крейдові дошки, таблиці, прилади тощо). Просторова організація класу має спонтанний характер. На третьому етапі (з середини XVII ст.) відзначаються перші спроби систематичної організації, зонування простору класу, створення функціональних осередків різного призначення, закріплення робочих місць за учнями. Обладнання класів фронтально орієнтованими рядами спеціалізованих учнівських меблів (столів з однобічним розміщенням робочих місць) у XVIII ст. можна вважати ознакою переходу до наступного періоду.

\section{Ключові слова:}

навчальний простір, школа, класне приміщення, просторова організація класу, шкільне меблювання, учнівські меблі, історія школи.

Вступ 1 Шкільна реформа в Україні передбачає зокрема також і зміни в організації освітнього простору школи. Питання організації простору та меблювання шкільного класу згідно з потребами сучасної педагогіки є актуальним та широко обговорюється в усьому світі. В контексті цього питання важливим є розуміння історичної генези простору школи, проте саме цей аспект видається не достатньо дослідженим. Найменш описаним $\epsilon$ якраз початковий період становлення простору масової школи. Наявні дослідження зосереджуються переважно на «індустріальному періоді» (XIX-XX ст.), найширше досліджується такий феномен XIX століття, як «парта» (Herman, Van Gorp, Simon, \& Depaepe, 2011; Moreno Martinez, 2005). Широкий огляд історії меблювання школи наведено у каталозі Шкільного музею компанії VS Vereinigte Spezialmöbelfabriken (2010), але ця робота охоплює лише період промислового виробництва учнівських меблів (орієнтовно з кінця XIX ст.). Щодо періоду до початку XIX ст., слід відзначити в першу чергу роботу Ланге (Lange, 1998), присвячену архітектурі шкіл, зокрема їх просторовій організації. Шкільне меблювання до XIX ст. розглядається лише оглядово або побіжно (Артеменко \& Мельохіна, 2014; Kühn, 2011).

\section{Мета дослідження}

Метою статті $є$ виявити та характеризувати особливості просторової організації та меблювання навчальних приміщень європейської масової школи на початкових етапах становлення та розвитку (орієнтовно XIII-XVII ст.), уточнити хронологічні рамки цих етапів. 


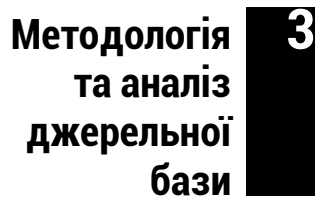

Основними методами дослідження $є$ історико-культурний та компаративний методи. Джерельною базою $€$ історичні зображення шкільного облаштування названого періоду в образотворчому мистецтві та в інших візуальних джерелах. Додатково залучались (за наявності) текстові свідчення та результати сучасних історико-культурних досліджень.

\section{Результати дослідження}

Розвиток масової освіти в Європі починається в часи пізнього Середньовіччя з появою як університетів, так і початкових цивільних шкіл (в першу чергу міських) (Боришанская, 1989). Основним візуальним джерелом щодо шкільного облаштування цього часу є книжкова мініатюра. Відомі ілюстрації дають досить характерну картину навчального приміщення з мінімальним обладнанням (рис. 4.1-4.3). Ці зображення стосуються здебільшого університетських класів, але можна припуска-

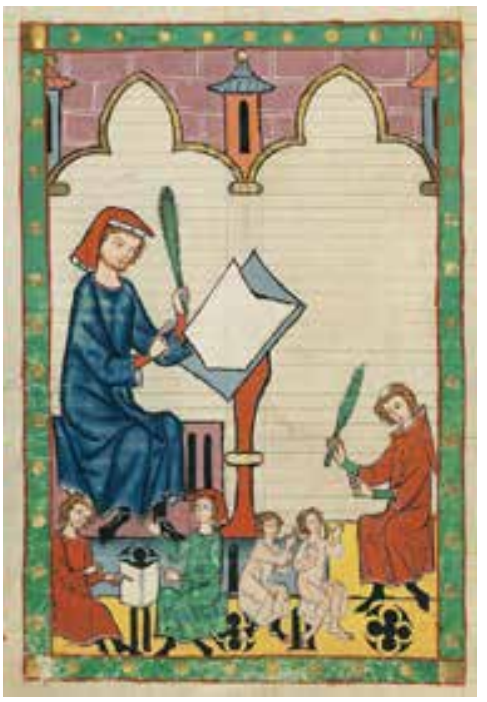

Рис. 4.1. Невідомий автор. Вчитель з Есслінгена. Манесський кодекс. Перша половина XIV ст.

Fig. 4.1. Unknown author. Schoolmaster of Esslingen. Manesse codex. First half of the XIV ct.

ти, що облаштування початкових шкіл було подібним або ще простішим. Смисловим центром класу $є$ вчитель, що нерідко сидить у великому парадному кріслі-кафедрі, навіть з дашком. Поруч розміщується пюпітр з книгою. Учні сидять на лавах або просто на підлозі, учнівських столів немає. Розміщення учнів $€$ скоріше спонтанним, без певної системи. Відомі також зображення університетських класів зі студентськими місцями, що обладнані столами (рис. 4.4). Втім, у міських (народних, граматичних) школах столів для учнів ще тривалий час не було передбачено. Про це, зокрема, свідчить Еразм Роттердамський у 1519 році, описуючи лондонську школу св. Павла (перша цивільна школа Англії, засновано 1509 р.): «Для всіх хлопчиків є лави, що і розміщено на однакових відстанях одна вище одної. В кожному класі таких шістнадцять, а той, хто в класі найкращий, має маленький стіл як відзнаку» (McDonnell, 1909). 
Деміург: ідеї, технології, перспективи дизайну 2019 Том 2 № 1 Demiurge: ideas, technologies, perspectives of design 2019 Vol. 2 No 1
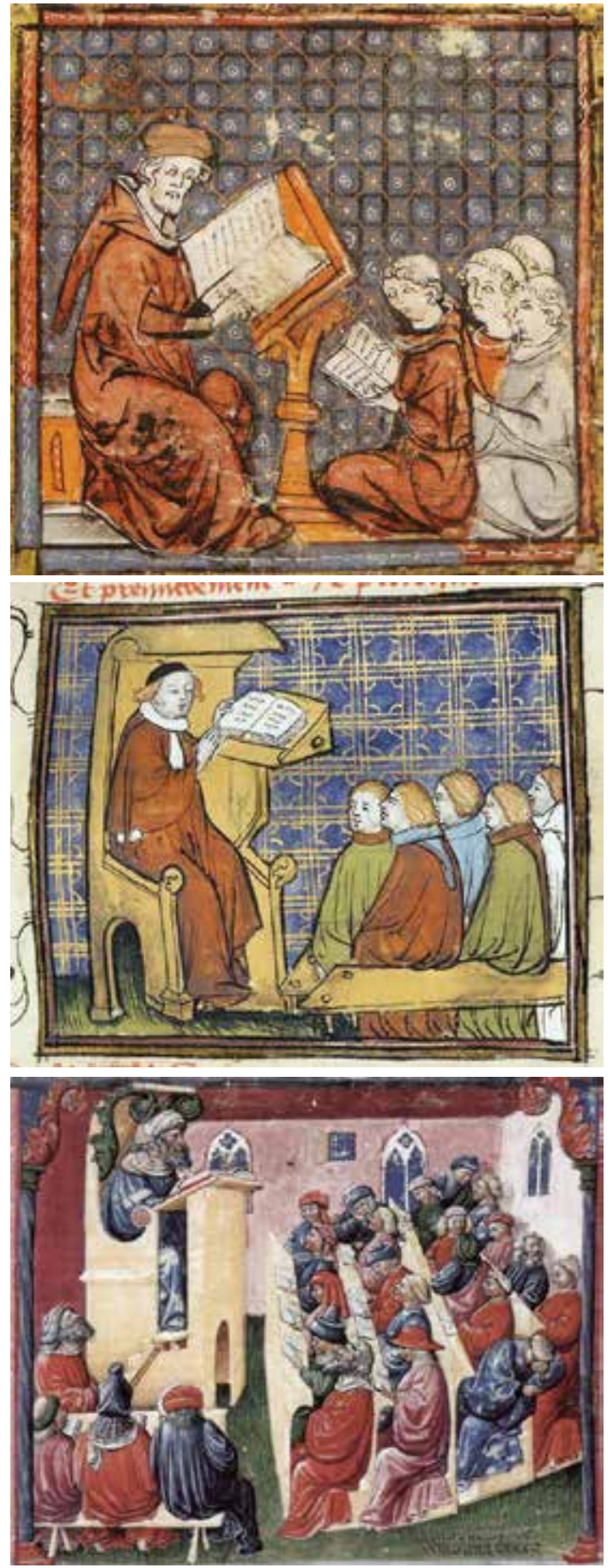

Рис. 4.2. Невідомий автор Курс філософії в Парижі. Великі французькі хроніки. Кінець XIV ст.

Fig. 4.2. Unknown author. Philosophy course in Paris. Grandes Chroniques de France. End of the XIV ct.

Рис. 4.3. Невідомий автор. Вчитель та учні. Французьке видання «De proprietatibus rerum» Бартоломея Англійського. 15 ст.

Fig. 4.3. Unknown author. Teacher and students. French edition of «De proprietatibus rerum» by Bartolomeus Anglicus. 15th ct.

Рис. 4.4. Л. Вотолінський. Генріх Алеманський в Болонському університеті. Друга половина XIV ст.

Fig. 4.4. L. de Voltolina. Henricus de Alemannia at Bologna University. Second half of the XIV ct.

Зміни в характері облаштування масової школи спостерігаються в період Реформації, що вочевидь пов'язано з початком становлення ступеневої системи шкільної освіти в Німеччині на основі концепцій Лютера та Меланхтона (Rupp, 1996). В цей час 
початкові школи ще переважно не мають спеціальних приміщень, розташовуються у житлових будинках. Про це свідчить, зокрема, німецька гравюра XVI ст. (рис. 4.5), де на задньому плані у дверному прорізі можна бачити ліжко. Приміщення на передньому плані водночас слугує вітальнею та класом, обладнане побутовими меблями (стіл, вкритий скатертиною, лави для сидіння). Місце вчителя не виділене. На іншій гравюрі 1592 року (рис. 4.6) видно шкільний клас більшого розміру, обладнаний різноманітними столами та лавами. Учні виконують різні види навчальної діяльності: пишуть, сидячи навколо столу, слухають лекцію, згуртувавшись навколо вчителя на лавах та на підлозі тощо. Робоче місце вчителя, як і на попередньому зображенні, не виділяється особливим характером сидіння. На стінах видно демонстраційне обладнання (таблиці, мірна лінійка, можливо, дошка для письма). Подібну картину дає ілюстрація до слова «школа» з книги Я. А. Коменського «Orbis Sensualium Pictus» 1658 року (Commenius, 1705) (рис. 4.7). До цього зображення додано пояснювальний текст такого змісту: «Вчитель (2) сидить у кріслі (3) учні (4) на лавах (5), їх вчать, вони вчаться. Перед ними дещо написано крейдою на дошці (6). Деякі сидять біля столу та пишуть (7), він [вчитель] виправляє їхні помилки (8). Дехто стоїть та декламує те, що мав вивчити на пам'ять (9). Деякі розмовляють одне з одним та поводяться нерозумно та безтурботно (10)...». Таким чином, обладнання класу складається з вчительського крісла з пюпітром, учнівських лавок та столу (як і на рис. 4.5, вкритого скатертиною), а також демонстраційної дошки для письма крейдою - тут, чи не вперше, цей звичний шкільний прилад впевнено ідентифікується як за зображенням, так і за текстом. У роботі «Закони добре влаштованої школи» (1652-57) (Коменский, 1982, с. 135) Я. А. Коменський пише: «Скільки класів, стільки має бути і навчальних кімнат, щоб кожний курс займався окремо та ніколи не відволікався стороннім шумом. Кожна навчальна кімната має бути облаштована кафедрою та достатньою кількістю лав; останні мають бути розташовані таким чином, щоб учитель постійно мав перед очима всіх учнів, що звернені до нього». Як видно, ані учнівські столи, ані крейдова дошка тут не згадуються як необхідні елементи шкільного меблювання. Втім, у «Законах...» Коменський пропонує використання у навчальному процесі засобів наочності: "Дуже корисно, якщо курс кожного класу буде розписано на стінах, дверях, вікнах, стовпах навчальної кімнати (чи то у вигляді висловів, чи коротких речень, або в емблемах та картинах)...» (Коменский, 1982, с. 135). Ймовірно, саме такі таблиці ми бачимо на гравюрі 1592 року (рис. 4.6).

У порівнянні з попереднім періодом у школі періоду Реформації можна відзначити такі особливості облаштування шкільного класу: зменшення ваги вчительського місця, непарадний характер його сидіння; облаштування учнівських місць не 
Деміург: ідеї, технології, перспективи дизайну 2019 Том 2 № 1 Demiurge: ideas, technologies, perspectives of design 2019 Vol. 2 No 1
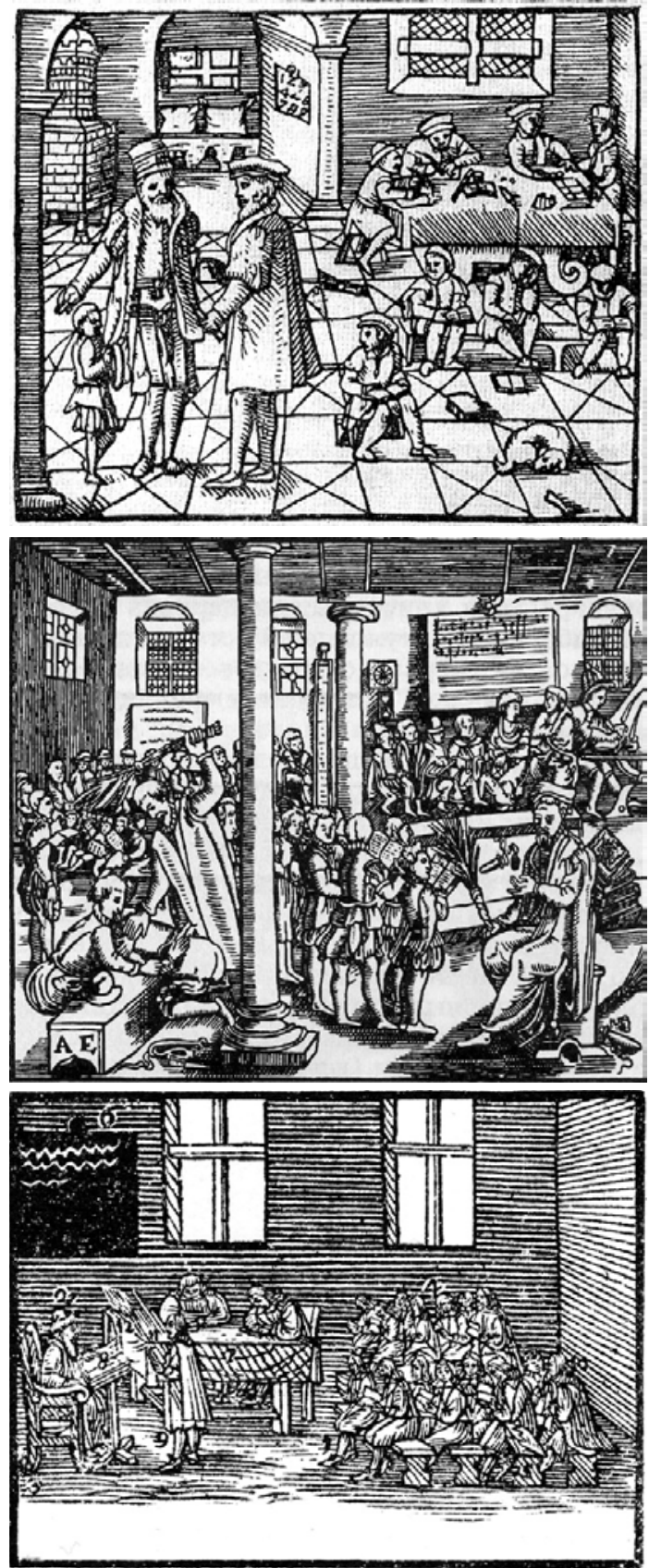

Рис. 4.5. Невідомий автор. Приватна школа в будинку вчителя. XVI ст.

Fig. 4.5. Unknown author. Private school in the teacher's house. XVI ct.
Рис. 4.6. Невідомий автор. Міська школа. 1592.

Fig. 4.6. Unknown author. Town school. 1592.

Рис. 4.7. Невідомий автор. Школа. "Orbis Sensualium Pictus» Я. А. Коменського. 1658.

Fig. 4.7. Unknown author. The School. "Orbis Sensualium Pictus» by J. A. Comenius. 1658.

лише лавами, але також столами для письмової роботи; поява демонстраційного обладнання (крейдова дошка, таблиці на стінах тощо). Але загалом школа зберігає характер житлового приміщення, для обладнання класу використовуються меблі, що не відрізняються від побутових.

Протягом XVII ст. з'являються також зображення спеціалізованих шкільних приміщень. Прикладом є картина Яна Стеена 
«Школа для хлопчиків та дівчат» (рис. 4.8). Великий клас, що зображено на картині, вочевидь, вже не $є$ житловим примі-

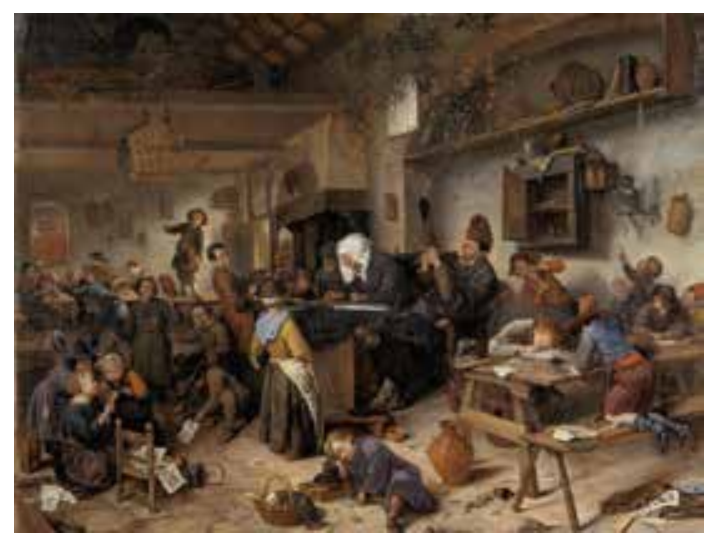

Рис. 4.8. Я. Стеен. Школа для хлопчиків і дівчат. 1670.

Fig. 4.8. J. Steen. A School for Boys and Girls. 1670.

щенням, а обладнано спеціально для потреб школи. Втім, меблювання класу, як і раніше, має скоріш спонтанний характер, а меблі за формами та конструкцією не відрізняються від побутових. Робоче місце вчителів обладнано столом та двома досить комфортними, але не парадними кріслами. Детальніше таке крісло видно на іншій картині Стеена, «Сільська школа» (рис. 4.9); подібне вчительське крісло бачимо і у Коменського (рис. 4.7). Приміщення захаращено побутовими предметами, учні працюють за звичайними столами, сидячи хто на лавах, хто на стільцях, хто навіть на діжці. Видно, що меблі виконано за помірами дорослої людини; для малолітніх учнів та учениць вони завеликі та незручні. Іншого облаштування клас не має, за виключенням невеликих полиць та деяких приладів (наприклад, пісочних годинників) на стінах. На стінах також розвішано невеличкі скриньки, що слугували учням за портфелі (два таких

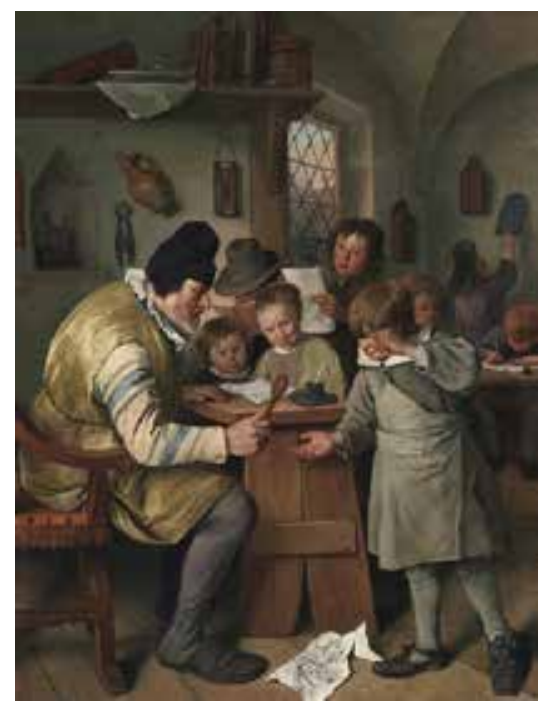

Рис. 4.9. Я. Стеен. Сільська школа. 1665.

Fig. 4.9. J. Steen. The Village School. 1665. 
портфелі ми бачимо на передньому плані на підлозі, учениці витягли з них та роздивляються кольорові картинки з птахами).

Картина Стеена дає чітке уявлення про організацію навчальної роботи: вона $є$ не фронтальною, а індивідуальною, кожен з учнів чи учениць виконує (чи не виконує) власне завдання. Врешті, столи з двостороннім розташуванням робочих місць і не дають можливості для фронтального навчання. Такий підхід до організації навчання добре ілюструє текст «Порядку шкільного» - статуту Львівської братської школи 1586 року: «... [хлопці] учитися мають порізно, Псалтиря чи граматики з розв'язуванням іiі та іншим багатьом потрібним наукам, як визначите на той час, згідно з потребою; (...) хлопці мають самі писати на таблицях кожен свою науку, видану їм од дидаскала, окрім малих, яким має писати сам дидаскал» (Шинкарук, 1988, с. 40). Втім, для нідерландської школи характерним є спільне навчання хлопчиків та дівчат, хоча і з певними елементами просторової гендерної сегрегації: видно, що за столами працюють лише хлопці. Вочевидь, така сегрегація на той час була системною, що підтверджується й іншими зображеннями, наприклад фасадними рельєфами (gevelsteen) голландських будівель (рис. 4.10). На цих рельєфах добре видно, що хлопці та дівчата розміщуються в різних частинах приміщення, і хлопці мають кращі умови для роботи та більшу увагу вчителя. Подібне ставлення до просторової організації спільного навчання спостерігається в Європі досить довго, принаймні до XIX століття (Kühn, 2011).

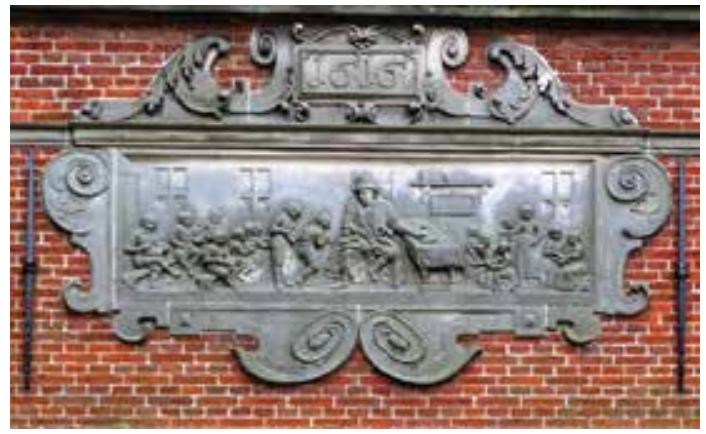

Рис. 4.10. Невідомий автор. Фасадний рельєф на будівлі сиротинця, Енкхейзен. 1616.

Fig. 4.10. Unknown author. Façade relief on the orphanage building in Enkhuizen. 1616.

Цікавим прикладом, що певним чином передвіщає початок нового етапу розвитку шкільного простору, є проект німецького архітектора Йозефа Фуртенбаха «Німецька шкільна будівля» (Furttenbach, 1649). Пропонована будівля є двоповерховою, на першому поверсі знаходиться житло для учнів та вчителів, на другому - два великі симетрично розташовані класи, позначені як «приміщення для хлопчиків» та «приміщення для дівчат» (на рис. 4.11 наведено половину плану другого поверху з одним класом). Таким чином, школа передбачає роздільне навчання хлопців та дівчат, але створює для тих та інших однакові умови. Робочі місця учнів та учениць обладнано довгими 


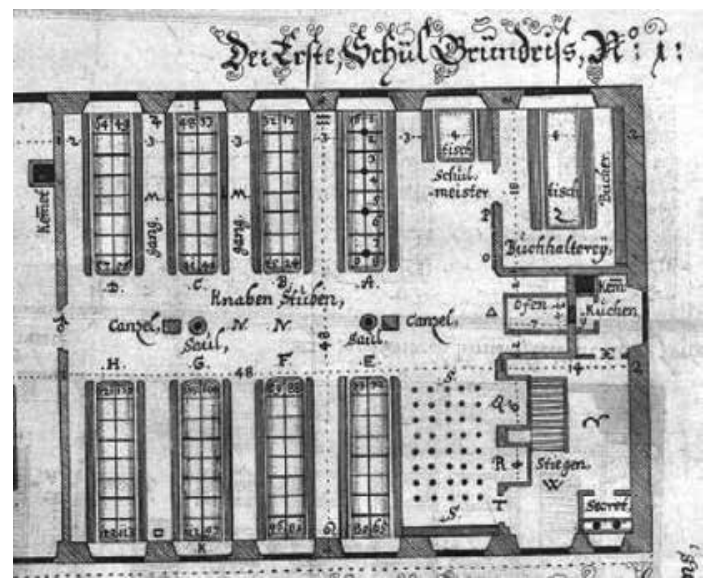

Рис. 4.17. Й. Фурттенбах. Німецька шкільна будівля. Фрагмент плану другого поверху (приміщення для хлопчиків). 1649.

Fig. 4.11. J. Furttenbach. German School Building. Fragment of the first floor plan (boys' chamber). 1649.

столами, до яких з обох боків додано такі самі довгі лави; кожен стіл розраховано на 16 учнів, по 8 з кожного боку; усього столів вісім, тобто наповнюваність класу 128 учнів (учениць). Варто відзначити, що поділ учнів у класі на число, кратне 8, відзначається, починаючи з часів Відродження (див. цитоване вище повідомлення Еразма про школу св. Павла) та аж до початку XIX ст. (скажімо, у школах Ланкастера, Lancaster, 1812). Hаведені розміри приміщення (48×48 футів) дозволяють приблизно визначити його площу у сучасних одиницях (орієнтовно 250 м², враховуючи, що розмір фута відрізнявся в різні часи та в різних місцевостях). Таким чином, на одного учня (ученицю) припадає близько 2 квадратних метрів, що задовольняє навіть сучасні вимоги щодо площі класів. Як можна бачити, в цьому проекті меблювання учнівських місць залишається в межах тих саме підходів, що були характерними для часів Реформації, з використанням меблів побутового типу (широких довгих столів з двостороннім розміщенням). Невелика дошка для письма крейдою (Р-О) вочевидь не призначена для роботи з цілим класом, оскільки для більшої частини учнів вона не видна. Можна дійти до висновку, що цей проект передбачає, як і у попередні часи, індивідуальну роботу учнів з власними завданнями. Новаціями проекту Фурттенбаха є, по-перше, забезпечення всіх учнів місцем для письма; по-друге, регулярне розміщення меблів з точним визначенням кількості місць за столом. По-третє, проектом передбачено виділення в об'ємі класу певних функціональних осередків, тобто зонування простору. Крім учнівських місць, встановлено окремий стіл вчителя з можливістю роботи з кількома учнями (Schulmeister). Для групової рецитації виділено окрему ділянку кімнати (S-S), де вбитими у підлогу цвяхами позначені місця для стояння учнів; поруч влаштовано вбудовані шафи для зберігання таблиць (Q, R); в окремому приміщенні знаходиться класна бібліотечка (Buchhalterey). При класі навіть передбачено туалет всередині будівлі (Secret). Як зазначає Ланге (Lange, 1998), проект Фурттенбаха є прикла- 
дом переходу від школи як «будинку вчителя» (персональної, вчителе-центрованої школи) до школи-інституції, що орієнтується вже не на особистість вчителя, а на певну навчальну програму. Втім, щодо розповсюдженості шкільних будівель такого типу у XVII ст. судити немає підстав.

В другій половині XVIII ст. у Європі виникає та поширюється прусська освітня система, однією з ознак якої є фронтальне навчання, тобто робота вчителя одночасно з цілим класом (Бим-Бад, 2015). Для забезпечення такої організації навчальної роботи початкові та середні школи починають обладнувати спеціалізованими, суто шкільними меблями, подібними до тих, що використовувались ще у середньовічних університетах (рис. 4.4): довгими столами з похилою поверхнею, при яких учні сидять на лавах лише з одного боку. Такі столи розміщуються рядами, фронтально обернені в один бік, у напрямку вчителя. Подібну просторову організацію та меблювання мали також Ланкастерські школи (Lancaster, 1812), що були широко розповсюдженими у першій половині XIX ст. Зразки облаштованих таким чином класів можна бачити у багатьох музеях традиційної архітектури, зокрема в експозиціях «Школа» в усіх скансенах України. Втім, відмова від двосторонніх столів побутового типу не була швидкою: за свідченням Морено Мартінеса (Moreno Martinez, 2005), ще у 1838 році в Іспанії публікувались рекомендації для шкіл щодо заміни таких столів односторонніми. Рядно-фронтальну організацію класу та облаштування навчальних приміщень масової школи спеціалізованими меблями можна розглядати як ознаку наступного періоду розвитку освітнього простору (орієнтовно з XVIII ст.); характеристика цього періоду виходить за межі цієї статті.

\section{Наукова новизна та практична значимість дослідження \\ 5}

Висновки 6
В статті вперше систематично описано особливості просторової організації та меблювання шкільних класів у початковому періоді розвитку масової шкільної освіти у Європі (орієнтовно XIII-XVIIст.), виділено ключові етапи зазначеного періоду.

На основі аналізу історичних джерел можна впевнено окреслити початковий період розвитку просторової організації та облаштування шкільного простору межами XIII-XVII ст. Ключовими ознаками цього періоду $€$ a) просторова організація класу, що придатна лише для індивідуальної роботи учнів, б) використання неспеціалізованого меблювання (побутових крісел, лав та столів). У цьому періоді можна виділити три етапи. Перший (XIII-XVI ст.) характеризується обладнанням лише вчительського місця (крісло-кафедра та стіл або пюпітр); учні бувало сиділи просто на підлозі. Другий етап (XVI - перша половина XVII ст.) вирізняється запровадженням столів для письмової роботи учнів, а також демонстраційного обладнання (крейдові дошки, табли- 
ці, прилади тощо). Просторова організація класу має спонтанний характер. На третьому етапі (з середини XVII ст.) відзначаються перші спроби систематичної організації, зонування простору класу, створення функціональних осередків різного призначення (для письма, рецитації, консультацій з вчителем, бібліотечки тощо), закріплення робочих місць за учнями. Запровадження рядно-фронтальної організації класу та використання спеціалізованих учнівських меблів (столів з однобічним розміщенням робочих) місць у XVIII ст. можна вважати ознакою переходу до наступного періоду розвитку освітнього простору. Уточнення характерних особливостей просторової організації та облаштування класів у наступних періодах розвитку є предметом подальших досліджень.

\section{Список бібліографічних посилань}

Артеменко, М.П., \& Мельохіна, О.О. (2014). Ілюстрація інтер'єрів навчальних приміщень у роботах митців епохи середньовіччя. В Nauka dzisiaj. Oferty. Szczecin (c. 107-110). Warszawa: Diamond trading tour.

Бим-Бад, Б.М. (2015). История государственной школы в Германии. Историко-педагогический журнал, 1, 140-151.

Боришанская, М.М. (1989). Ведущие тенденции развития школы в странах Западной Европы в XII-XIV вB. (к постановке проблемы). В Западноевропейская средневековая школа и педагогическая мысль. (Выпуск 1, с. 114-122). Москва.

Коменский, Я.А. (1982). Избранные педагогические сочинения (Т. 2). Москва: Педагогика.

Шинкарук, В.І. (Ред.). (1988). Пам'ятки братських шкіл на Україні: кінець XVI - початок XVII ст.: тексти і дослідження. Київ: Наукова думка.

Commenius, J.A. (1705). Orbis Sensualium Pictus. London, England: John Sprint.

Furttenbach, J. (1649). Teutsches Schulgebäw. Augspurg, Germany: Schultes.

Herman, F., Van Gorp, A., Simon, F., \& Depaepe, M. (2011). The school desk: from concept to object. History of Education, 40(1), 97-117. https://doi.org/10.1080/0046760X.2010.508599.

Kühn, C. (2011). Learning environments for the 21st century. In Designing for Education: Compendium of Exemplary Educational Facilities 2011 (p. 1923). Paris, France: OECD Publishing. https://dx.doi.org/10.1787/9789264112308-en.

Lancaster, J. (1812). The British System of Education: Being a Complete Epitome of the Improvements and Inventions. Washington, DC: Joseph Milligan.

Lange, H. (1998). Der Schulbau der frühen Neuzeit als Ausdruck von politisch-gesellschaftlicher Verfassung und Schulleben. Bibliothek für Bildungsgeschichtliche Forschung des DIPF. Retrieved from http://www.historische-bildungsforschung-online.de/hbo/hbo_set. html?ld=50\# oben.

McDonnell, M.F.J. (1909). A history of St. Paul's School. London, UK: Chapman and Hall.

Moreno Martinez, P.L. (2005). History of School Desk Development in Terms of Hygiene and Pedagogy in Spain (1838-1936). In M. Lawn, I. Grosvenor (Eds.) Materialities of schooling: design, technology, objects, routines (pp. 71-95). Oxford, UK: Symposium Books.

Rupp, H.F. (1996). Philipp Melanchthon (1497-1560). PROSPECTS: the quarterly review of comparative education, 26(3), 611-621.

\section{References}


Artemenko, M.P., \& Melokhina, O.O. (2014). Iliustratsiia interieriv navchalnykh prymishchen u robotakh myttsiv epokhy serednovichchia [An illustration of the interiors of educational premises in the works of the artists of the Middle Ages]. In Nauka dzisiaj. Oferty. Szczecin [Science today. Offers. Szczecin] (pp. 107-110). Warszawa, Poland: Diamond trading tour [in Ukrainian].

Bim-Bad, B.M. (2015). Istoriia gosudarstvennoi shkoly $\vee$ Germanii [The history of the public school in Germany]. Istoriko-pedagogicheskii zhurnal, 1, 140-151 [in Russian].

Borishanskaia, M.M. (1989). Vedushchie tendentcii razvitiia shkoly v stranakh Zapadnoi Evropy V XII-XIV vv. (k postanovke problemy) [Leading school development trends in Western Europe in the XII-XIV centuries (to the formulation of the problem)]. In Zapadnoevropeiskaia srednevekovaia shkola i pedagogicheskaia mysl [Western European medieval school and pedagogical thought] (Issue 1, pp. 114-122). Moscow [in Russian].

Commenius, J.A. (1705). Orbis Sensualium Pictus. London, England: John Sprint.

Furttenbach, J. (1649). Teutsches Schulgebäud [Teutsches school building]. Augspurg, Germany: Schultes [in German].

Herman, F., Van Gorp, A., Simon, F., \& Depaepe, M. (2011). The school desk: from concept to object. History of Education, 40(1), 97-117. https://doi.org/10.1080/0046760X.2010.508599 [in English].

Komenskii, la.A. (1982). Izbrannye pedagogicheskie sochineniia [Selected pedagogical works] (Vol. 2). Moscow: Pedagogika [in Russian].

Kühn, C. (2011). Learning environments for the 21st century. In Designing for Education: Compendium of Exemplary Educational Facilities 2011 (p. 1923). Paris, France: OECD Publishing. https://dx.doi.org/10.1787/9789264112308-en [in English].

Lancaster, J. (1812). The British System of Education: Being a Complete Epitome of the Improvements and Inventions. Washington, DC: Joseph Milligan [in English].

Lange, H. (1998). Der Schulbau der frühen Neuzeit als Ausdruck von politisch-gesellschaftlicher Verfassung und Schulleben [The school construction of the early modern period as an expression of political-social constitutionand school life]. BibliothekfürBildungsgeschichtliche Forschung des DIPF. Retrieved from http://www.historische-bildungsforschung-online.de/ hbo/hbo_set.html?ld=50\#oben [in German].

McDonnell, M.F.J. (1909). A history of St. Paul's School. London, UK: Chapman and Hall [in English].

Moreno Martinez, P.L. (2005). History of School Desk Development in Terms of Hygiene and Pedagogy in Spain (1838-1936). In M. Lawn, I. Grosvenor (Eds.) Materialities of schooling: design, technology, objects, routines (pp. 71-95). Oxford, UK: Symposium Books [in English].

Rupp, H.F. (1996). Philipp Melanchthon (1497-1560). PROSPECTS: the quarterly review of comparative education, 26(3), 611-621 [in English].

Shynkaruk, V.I. (Ed.). (1988). Pamiatky bratskykh shkil na Ukraini: kinets XVI - pochatok XVII st.: teksty $i$ doslidzhennia [Monuments of fraternal schools in Ukraine: the end of the XVI the beginning of the XVII century: texts and research]. Kyiv: Naukova dumka [in Ukrainian]. 